\title{
Esegiël 33 as wentelpunt in die boek van Esegiël
}

\author{
Author: \\ Herrie F. van Rooy ${ }^{1}$ \\ Affiliation: \\ ${ }^{1}$ Research Unit for \\ Reformed Theology and the \\ Development of the South \\ African Society, North-West \\ University, Potchefstroom \\ Campus, South Africa

\section{Correspondence to:} \\ Herrie van Rooy \\ Email: \\ herrie.vanrooy@nwu.ac.za

\section{Postal Address:} \\ Faculty of Theology, \\ North-West University, \\ Potchefstroom 2520, \\ South Africa \\ Dates: \\ Received: 08 Mar. 2011 \\ Accepted: 18 July 2011 \\ Published: 02 Nov. 2012 \\ How to cite this article: \\ Van Rooy, H.F., 2012, 'Esegiël \\ 33 as wentelpunt in die boek \\ van Esegiël' In die Skriflig/ \\ In Luce Verbi 46(1), 6 pages. \\ http://dx.doi.org/10.4102/ \\ ids.v46i1.51
}

C 2012. The Authors. Licensee: AOSIS OpenJournals. This work is licensed under the Creative Commons Attribution License.
Baie geleerdes het Esegiël as die inleiding tot die laaste groot gedeelte van die boek (Eseg 33-48) beskou, met terugverwysing na die eerste gedeelte van die boek (Eseg 1-24). Esegiël 33:1-20 het op verskillende maniere gebruik gemaak van en voortgebou op gedeeltes wat vroeër in die boek voorgekom het, veral die gedeeltes wat oor die roeping van die profeet in Esegiël 1-3 handel, asook Esegiël 18 wat die mens se persoonlike verantwoordelikheid beklemtoon. Die voorstel wat in hierdie artikel gemaak is, is dat die hoofstuk in die finale vorm van die boek 'n wentelfunksie het, om aan die een kant kortliks die boodskap van die profeet voor die val van Jerusalem saam te vat, maar om ook die leser vir die boodskap van Esegiël 34-48 voor te berei. Die twee uitsprake in Esegiël 33:23-33 dui op die toestand van die mense in Jerusalem, asook van die mense in ballingskap. Dit dui dus op die toestand van die twee groepe mense teen die tyd van die val van Jerusalem. Hierdie gedeeltes, soos ook die beklemtoning van die mens se verantwoordelikheid met die moontlikheid van bekering en herstel, antisipeer die boodskap van verlossing en herstel wat op Esegiël 33 sou volg.

Ezekiel 33 as pivotal point in the book of Ezekiel. Many scholars regarded Ezekiel as the introduction to the last major part of the book (Ezk 33-48), with references to the first part of the book (Ezk 1-24). Ezekiel 33:1-20 made use, in diverse ways, of previous sections in the book, especially the sections dealing with the call of the prophet in Ezekiel 1-2, as well as Ezekiel 18, with its emphasis on the personal responsibility of the people of God. The proposal of this article was that the chapter served as a pivotal point in the final form of the book. On the one hand it summarised the message of the first part of the book, but it also prepared the people for the message of the final part of the book. The two oracles in Ezekiel 33:23-22 pointed to the circumstances of the people in Jerusalem, as well as that of the exiles, at the time of the fall of Jerusalem. These oracles and the emphasis on the personal responsibility of the people pointed to the message of salvation and restoration following in Ezekiel 34-48.

\section{Inleiding}

Die plek van Esegiël 33 in die boek van Esegiël word op verskillende maniere beoordeel. Baie geleerdes beskou hierdie hoofstuk as die inleiding tot die laaste groot gedeelte van die boek (Eseg 33-48). Ander geleerdes beskou Esegiël 33:1-20 as 'n latere toevoeging tot die boek. Hulle oordeel dat Esegiël 33:21-22 logies op Esegiël 24 volg en dat die invoeging van Esegiël 33:1-20 die logiese opeenvolging versteur. Diegene wat die eerste standpunt huldig, wys daarop dat Esegiël 33:1-20 op verskillende maniere gebruik maak van en voortbou op gedeeltes wat vroeër in die boek voorkom. Dit is veral Esegiël 1-3, wat handel oor die roeping van die profeet, en Esegiël 18 , wat die mens se persoonlike verantwoordelikheid beklemtoon. Die voorstel wat in hierdie artikel gemaak word, is dat Esegiël 33 in die finale vorm van die boek 'n wentelfunksie het, om aan die een kant kortliks die boodskap van die profeet voor die val van Jerusalem saam te vat, maar om ook die mense vir die boodskap van Esegiël 34-48 voor te berei en dit te antisipeer. Die bespreking wat hierop volg, gee eers aandag aan die wyse waarop die betrokke hoofstuk in die verlede beskou is, veral ten opsigte van die plek van die hoofstuk in die struktuur van die boek. Daarna volg ' $n$ bespreking van die inhoud van die hoofstuk, met laastens ' $n$ aanduiding van hoe die hoofstuk as wentelpunt in die boek funksioneer.

\section{Die plek van Esegiël 33 in die boek: 'n Kort navorsingsoorsig}

Cooke (1970) is 'n goeie voorbeeld van 'n navorser wat Esegiël 33 as die inleiding tot die derde deel van Esegiël beskou. Hy verdeel die boek in drie dele, naamlik Esegiël 1-24, 25-32 en 33 48, hoewel die laaste deel wel in Esegiël 33-39 en 40-48 (ibid. 1970:xvi) onderverdeel kan word. Esegiël 33-48 handel dan oor die komende herstel van Israel. Hy wys ook daarop dat die reeks datums wat in die boek voorkom hierdie indeling onderskryf (ibid. 1970:xvi-xix). Volgens sy interpretasie strek die datums in die eerste deel van Julie 593 tot Januarie 588. Die datums in die 
tweede deel (die uitsprake teen die nasies) strek waarskynlik van Januarie 587 tot Maart 585, met net een datum uit ' $n$ latere periode, naamlik die uitspraak teen Egipte in Esegiël 29:17-21 wat van April 571 dateer. In die laaste deel van die boek kom slegs twee datums voor. In Esegiël 33:21 word die nuus oor die val van Jerusalem gedateer in Januarie 585, terwyl die gesig van Esegiël 40-48 gedateer word in Oktober 573. Hy sien hoofstuk 33 dus as die oorgang na die derde deel (ibid. 1970:363-364).

Hy verdeel Esegiël 33 in vier dele. In vers 1-9 word die profeet as wagter aangestel wat die volk moet waarsku. Hierdie gedeelte gryp terug na Esegiël 3:16-21, maar hy dink dit hoort eerder hier (Cooke 1970:363). Esegiël 33:10-20 dui daarop dat God elke mens volgens sy verdienste sal vergeld. Die gedeelte stel dieselfde beginsel as Esegiël 18. Esegiël 33:21-29 bring die nuus oor die val van Jerusalem. Cooke (1970:363) dink dat hierdie gedeelte weer verband hou met Esegiël 3:24-27 en 24:26-27. Esegiël 33:30-33 is 'n uitspraak gerig aan die ballinge. Die vier gedeeltes in Esegiël 33 dui op 'n keerpunt in Esegiël se bediening.

Zimmerli (1979:1-2) onderskei dieselfde drie hoofgedeeltes in die boek, en beskou hoofstuk 33 ook as die begin van 'n nuwe afdeling. Hy verdeel die hoofstuk in dieselfde vier gedeeltes as Cooke, en sien ook die verbinding met Esegiël 3:16-21 en Esegiël 18. Zimmerli (1979:71) skryf die finale vorm van die boek aan die skool van Esegiël toe. Hy beskou die invoeging van die uitsprake teen die nasies tussen Esegiël 24:25-27 en Esegiël 33:21 as 'n produk van die werk van die skool. Hulle het daardie uitsprake daar ingevoeg omdat hulle gemeen het dat die oordeel oor die nasies 'n keerpunt in die lot van Israel sou bewerkstellig (ibid. 1979:72). Die invoeging van Esegiël 33:1-20 is ook deur hulle gedoen. Zimmerli (1983:182) beskou dus ook hierdie hoofstuk as die inleiding tot die derde gedeelte van die boek wat verlossing verkondig. Hy oordeel dat Esegiël 33:1-20 doelbewus hier geplaas is. Hy beskou Esegiël 33:1-20 as 'n tweede roeping van die profeet vir die fase na die val van Jerusalem (ibid. 1983:183). Hy verdeel die gedeelte dan ook verder in Esegiël 33:2-6, 7-9, 10-11 en 12-20. Esegiël 33:21-22 is eintlik 'n direkte opvolging van Esegiël 24:25-27 (ibid. 1983:191).

Cooper (1994:39) verdeel die boek in vier dele. Hy beskou Esegiël 1-3 as 'n aparte onderafdeling wat oor die roeping van die profeet handel. Verder handhaaf hy die verdeling van Esegiël 4-24, 25-32 en 33-48. Hy beskou Esegiël 33 ook as 'n keerpunt in die boek (ibid. 1994:291). Esegiël 33:1-24 dien om die gedeelte aan Esegiël 1-24 te verbind. Die verkondiging van die val van Jerusalem in Esegiël 33:21 dien daartoe om die profeet Esegiël se voorafgaande profetiese werk te bevestig. Esegiël 33:22-33 dui daarop dat die volk hulle nog nie bekeer het nie. Hy verdeel hoofstuk 33 in drie dele. Vers $1-9$ is ' $n$ oproep om na die wagter te luister, vers 10-20 moedig hulle aan om van die kwaad afskeid te neem en vers 21-33 handel oor die val van Jerusalem en Israel se onbekeerlikheid (ibid. 1994:292).

Clements (1996:6) aanvaar, soos Cooper, die verdeling van die boek in vier dele, naamlik Esegiël 1-3, 4-24, 25-32 en
33-48. Hoofstuk 33 dien om 'n brug na hoofstuk 24 te bou, terwyl die hoofstukke tussen-in iets van 'n ruspouse verteenwoordig (ibid. 1996:150). Esegiël 33:21 en 22 is veral belangrik. Hulle bring die boodskap van die val van Jerusalem wat die woorde van die profeet aan die volk bevestig, en met die aanbreek van hierdie boodskap kry die profeet die gebruik van sy stem terug. Hy kan dus nou 'n nuwe boodskap aan die volk bring (ibid. 1996:151). Hy verdeel egter die hoofstuk in drie dele, naamlik Esegiël 33:120, 21-22 en 23-33.

Allen (1994:xxv) aanvaar ook die tradisionele driedeling van die boek. Hoofstuk 33 is aan die begin van die derde afdeling wat veral terugkyk na die eerste deel van die boek. Die verkondiging van die val van Jerusalem in Esegiël 33:21-22 is die kern van hierdie hoofstuk. Esegiël 33:23-29 is 'n indirekte boodskap van hoop wat dit vir die ballinge duidelik maak dat hulle nie hulle reg op die land as hulle erfenis verbeur het nie (ibid. 1994:xxxi). Hy behandel egter 33:1-20 en 21-33 as twee aparte eenhede. Esegiël 33:1-20 word afgegrens deur die boodskapperformule in vers 1 en die nuwe datum in vers 21 (Allen 1990:142). Die opdrag aan die profeet om met die volk te praat in Esegiël 33:2, 7, 10 en 12 verdeel Esegiël 33:1-20 in vier gedeeltes. Hy aanvaar egter nie die algemene standpunt dat die gedeelte in twee hoofdele, Esegiël 33:2-9 en 10-20, verdeel kan word nie. Hy meen dat die gebruik van 'die kinders van jou volk' in Esegiël 33:2, 12 en 17 eerder dui op 'n groter verdeling by vers 12. In Esegiël 33:2-20 kom daar 'n patroon voor dat God die profeet aanspreek, waarna die profeet die volk aanspreek. Die gebruik van 'die huis van Israel' in Esegiël 33:11 gryp terug na vers 7. Die direkte aanspreek van 'die huis van Israel' in vers 11 en 20 het die krag van parallelle afsluitings. Albei gedeeltes word deur twisgesprekke in Esegiël 33:10-11 en 17-20 afgesluit (ibid. 1990:142). Hy verdeel Esegiël 33:21-33 in die twee dele, soos gewoonlik gedoen word (ibid. 1990:150). Esegiël 33:21-22 bevat die aankondiging van die val van Jerusalem, terwyl Esegiël 33:22-33 'n uitgebreide uitspraak van God is wat deur die boodskapperformule in vers 23 ingelei word. Die tweede gedeelte verdeel hy in twee onderafdelings, Esegiël 33:24-29 en 30-33. Albei word ingelei deur die Here wat die profeet aanspreek.

Block (1998:3) verdeel die boek in twee hoofdele, Esegiël 1-24 en 25-48. Hy wys daarop dat Esegiël 25:1 'n groot verdeling in die werk van die profeet aandui. Dit is wel moontlik dat die vervulling van die profeet se woorde in hoofstuk 33 en verder in 'n vroeëre versameling van die boek direk op Esegiël 24 gevolg het, maar die finale redakteurs van die boek het die uitsprake van die nasies tussen Esegiël 24 en 33 geplaas. Hy oordeel egter dat die uitsprake teen die nasies die begin is van die verkondiging van hoop aan die volk Israel. Die oordeel oor die nasies het vir die volk die boodskap ingehou dat die nasies nou die voorwerp van God se oordeel word, iets wat vir Israel hoop ingehou het (vgl. ibid. 1998:3-4). Hierdie standpunt van Block hou in dat Esegiël 33 nie as die groot wentelpunt gesien kan word nie, maar bloot as die begin van die positiewe verkondiging van hoop, terwyl Esegiël 25-32 'n negatiewe verkondiging van hoop is. 
Esegiël 33 is dus die begin van die positiewe boodskap van hoop vir Israel (Block 1998:234-235). Vir Block (1998:236) is dit duidelik dat die redakteurs van die boek Esegiël 33 as 'n eenheid aangebied het. Alhoewel daar gewoonlik vyf eenhede onderskei word, vorm die eerste twee (Eseg 33:1-20) 'n onderafdeling, gevolg deur die aankondiging van die val van Jerusalem in Esegiël 33:21-22. Die laaste twee gedeeltes vorm weer 'n eenheid deur te wys op die opstandigheid van die mense in Jerusalem en van die ballinge in Babel. In Esegiël 33:1-20 beskou hy 1-9 en 10-20 as twee onderafdelings (ibid. 1998:236-237). In Esegiël 33:23-33 onderskei hy weer 23-29 en 30-33 as twee onderafdelings (ibid. 1998:257).

Joyce (2009:42) verdeel die boek in meer eenhede as wat normaalweg gedoen word, alhoewel sommige van die eenhede wat hy onderskei by ander geleerdes onderafdelings van groter eenhede sou gewees het. Sy indeling is soos volg:

- Hoofstuk 1-3: Die roeping van die profeet.

- Hoofstuk 4-24: Oordeel oor Juda en Jerusalem.

- Hoofstuk 25-32: Uitsprake teen die nasies.

- Hoofstuk 33: Die keerpunt in die boek.

- Hoofstuk 34-37: Verwagtinge oor die herstel van Juda.

- Hoofstuk 38-39: Gog en Magog.

- Hoofstuk 40-48: Die gesig van die herstelde tempel.

Volgens Joyce (2009:190) is Esegiël 33 die keerpunt in die boek. Hy wys daarop dat die hoofstuk raakpunte het met vorige hoofstukke, veral Esegiël 3, 18 en 24. Joyce (2009:191195) verdeel Esegiël 33 in verse 1-9, 10-20, 21 en 22, 23-29 en 30-33.

In hierdie bydrae word veral aandag gegee aan die teks van Esegiël in sy finale vorm. Alhoewel dit heeltemal moontlik is dat Esegiël 33:1-20 al 'n redelike groot versameling van die boek veronderstel (Klein 2008:312), is die vraag wat hier gevra word wat die plek van daardie gedeelte in die finale vorm van die boek is. Klein aanvaar ook die basiese driedeling van die boek in Esegiël 1-24, 25-32 en 33-48, met 'n eie plek aan Esegiël 40-48 (ibid. 2008:7). Sy meen egter dat die derde deel wesentlik met Esegiël 33:21 begin. Esegiël 33:23-29 en 30-33 verkondig in aansluiting hierby oordeel oor sowel die agtergeblewenes in Jerusalem as die mense wat in ballingskap verkeer (ibid. 2008:32).

Renz (1999:60) beskou ook Esegiël 33 as 'n wentelpunt in die boek. Die deel daarvoor bevat veral oordeelsuitsprake, terwyl dit wat daarop volg meer polities en nadenkend is. Esegiël 33:21-22 vorm in die besonder die keerpunt. Die datum wat in Esegiël 33:21 voorkom, word geformuleer soos die datums wat dui op 'n openbaring wat van God af kom. Juis dit beklemtoon die belang van hierdie datum (ibid. 1999:102). Die nuwe situasie het ook meegebring dat Esegiël nou meer openlik kon beweeg en met die volk in gesprek tree (Lemke 1984:166).

Alhoewel die mees algemene standpunt is dat die boek in drie dele verdeel kan word, naamlik Esegiël 1-24, 25-32 en $33-48$, is daar geleerdes wat die eerste deel in Esegiël 1-3 en 4-24 wil verdeel en andere wat Esegiël 33-48 in 33-39 en 40-
48 wil verdeel. Hierdie verdere onderverdeling het egter nie besondere implikasies vir die beoordeling van die plek van Esegiël 33 in die boek nie. Block se standpunt wyk af van die konsensus, met die verdeling van die boek in twee hoofdele, Esegiël 1-24 en 25-48. Verder is dit algemeen dat daarop gewys word dat veral Esegiël 33:1-20 terugverwys na Esegiël 1-24. Esegiël 33:21-33 het 'n belangrike verkondiging van oordeel, vir sowel die mense in ballingskap as die mense in Jerusalem na die val van die stad. Die ontleding van Esegiël 33 wat hieronder volg, dui egter aan dat die wentelposisie van die hoofstuk nie net afhang van die terugverwysing na die eerste deel van die boek, of ook die berig van die val van Jerusalem nie, maar dat die hoofstuk ook op 'n duidelike wyse die verkondiging wat daarop volg, antisipeer.

\section{Esegiël 33: Struktuur en inhoud Struktuur}

'n Algemene standpunt onder geleerdes is dat die boek van Esegiël een van die duidelikste gestruktureerde boeke in die Ou Testament is (vgl. bv. Joyce 2009:42). Die driedeling wat die meeste geleerdes in die boek vind, dien gewoonlik as een van die sterkste argumente ten gunste hiervan. Die rangskikking van profesieë voor die val van Jerusalem in Esegiël 1-24, die profesieë teen die nasies in Esegiël 25-32 en die profesieë met hoop vir die toekoms vanaf hoofstuk 33 ondersteun hierdie standpunt. Vir die beoordeling van die funksie van 'n hoofstuk in die boek van Esegiël is die posisie van die betrokke hoofstuk in hierdie struktuur natuurlik van belang. Daar is egter twee ander sake wat hierby in ag geneem moet word.

In die eerste plek kom daar 'n uitgebreide getal datums in die boek voor wat in die opset van die boek'n belangrike rol speel. Heelwat geleerdes beskou die datums as histories betroubaar, maar die historiese betroubaarheid is nie van soveel belang vir die beoordeling van die struktuuraanduidings wat die datums bied nie. Tweedens bevat die boek 'n hele aantal vaste formules verspreid deur die boek wat ook vir die uiteensetting van die boek in verskillende onderafdelings van groot belang is.

Die verwysing na die dertigste jaar in Esegiël 1:1 is steeds enigmaties. Daar is egter 'n verdere veertien datums wat normaalweg die patroon volg dat die datum verwys na die jaar van die ballingskap van koning Jojagin, dan die maand en dan die dag van die maand. Sulke datums kom voor in Esegiël 1:2-3, 8:1, 20:1, 24:1, 26:1, 29:1, 17, 30:20, 31:1, 32:1, 17, 33:21 en 40:1. In Esegiël 3:16 word 'n datum met 'n ander patroon aangetref, naamlik sewe dae na die eerste datum. Block (1997:26) wys daarop dat 'n hele aantal van die datums in die uitsprake teen Egipte in Esegiël 29:1-32:32 voorkom, maar dat die datums verder deur die boek versprei is en 'n kronologiese raamwerk vir die werk van die profeet bied. Block (1997:28-29) bied ook 'n tabel waarin hy die datums in Esegiël plaas teen die agtergrond van die hele periode waarin Esegiël geleef het, asook belangrike gebeure daarvoor en daarna. Hy begin by die troonsbestyging van Josia en volg 
die geskiedenis tot by die toestemming wat Cyrus gegee het dat die Jode na hulle eie land kan terugkeer. Dit is wel so dat vyf van hierdie veertien datums in die vier hoofstukke van die profesieë teen Egipte voorkom. Die datums in Esegiël begin met sy roeping in 593 v.C. (die vyfde dag van die vierde maand van die vyfde jaar van die ballingskap van Jojagin). In 592 volg dan die datum van Esegiël 8:1, met die eerste tempelvisioen op die vyfde dag van die sesde maand in die sesde jaar, met daarna die datum van Esegiël 20:1, in 591 v.C. Die versameling van datums waarna Block verwys, moet egter verbind word aan ander datums wat elders in die $\mathrm{Ou}$ Testament aangetref word. Volgens 2 Konings 25:1 het die beleg van Jerusalem op die tiende dag van die tiende maand in die negende jaar (van Sedekia) begin. Dit is dieselfde datum wat in Esegiël 24:1 vermeld word. Die datum is dus ook die datum van die afsluiting van die eerste deel van die boek toe Esegiël se vrou gesterf het en hy begin het om te swyg. Die datum in Esegiël 26:1 is problematies omdat die datum nie die maand vermeld nie. Dit noem net die eerste dag van die maand in die elfde jaar. Esegiël 26:2 verwys na die val van Jerusalem sodat die datum wel moet dui op 'n tyd kort na die val van Jerusalem, op die negende dag van die vierde maand van die elfde jaar, volgens 2 Koning 25:3. Die berig van die val van Jerusalem het Esegiël op die vyfde dag van die tiende maand van die twaalfde jaar bereik sodat dit eerder moontlik is dat die uitspraak teen Tirus gedateer moet word op die eerste dag van die elfde maand van die twaalfde jaar, soos wat Block (1997:29) wil doen. Die grootste groep datums kom dus voor van die tyd toe die beleg van Jerusalem begin het tot kort nadat die berig van die val van Jerusalem Esegiël bereik het. Agt van die veertien datums val in die periode vanaf die tiende dag van die tiende maand van die negende jaar tot die vyftiende dag van die twaalfde maand van die twaalfde jaar. Dit is dus van die beleg van Jerusalem se begin tot ongeveer twee maande nadat die nuus van die val Esegiël bereik het.

In die boek self word die datums van die profesieë teen die nasies saamgegroepeer in Esegiël 25-32, selfs ook die laaste datum in die boek, by die uitspraak teen Egipte wat in Esegiël 29:17 gedateer word. Dit beteken dat vyf datums in die eerste deel van die boek aangetref word, sewe in die profesieë teen die nasies en net twee in die laaste gedeelte, naamlik Esegiël 33:21 en 40:1. Laasgenoemde datum lei die groot visioen van 40-48 in. Dit beteken dus dat in die gedeelte van 33-39 net een datum in Esegiël 33:21 aangetref word wat dus vir die strukturering van die boek baie belangrik is.

Verskillende geleerdes het op die gebruik van sekere standaardformules in die boek van Esegiël gewys (vgl. bv. Block 1997:30-39). Vir die doel van hierdie bespreking is veral drie formules van belang.

Die eerste van hierdie drie formules is die bekende inleiding tot die ontvangs van 'n profetiese uitspraak wat van die Here

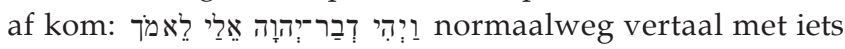
soos: 'Die woord van die Here het tot my gekom'. Block (1997:32) wys daarop dat hierdie formule meer as vyftig keer in die boek voorkom, met die meeste daarvan in Esegiël 11:14-39:29. Hierdie formule word gebruik om 'n uitspraak van God aan te dui.

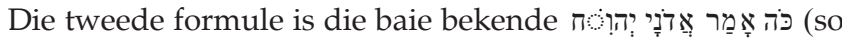
sê die Here HERE). Hierdie formule, wat bekend staan as die boodskapperformule, kom meer as 120 keer in Esegiël voor. Dit beklemtoon die rol van die profeet as boodskapper wat die boodskap oordra van die Een wat hom gestuur het (Block 1997:32-33).

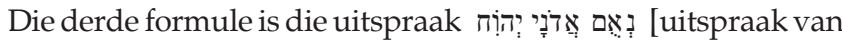
die Here HERE]. Hierdie bevestigingsformule kom 85 keer in Esegiël voor, waarvan 20 keer aan die einde van 'n uitspraak wat deur die boodskapperformule ingelei is. Volgens Block kom dit ook 27 keer voor om die einde van 'n paragraaf aan te dui en om 'n verandering in die fokus in 'n uitspraak aan te dui. In die ander gevalle kom dit voor in die middel van 'n vers waar dit die gang van die uitspraak versteur, met retoriese effek (Block 1997:33). Die gebruik van 'n datum en hierdie formules kan 'n mens help om die struktuur en samehang van 'n gedeelte te bepaal. Die profesieë teen die nasies sluit in Esegiël 32:32 af met die bevestigingsformule (dit is 'n uitspraak van die Here HERE). Esegiël 33 begin dan met die inleidingsuitspraak 'So sê die Here', wat dus 'n nuwe gedeelte inlei.

Benewens hierdie drie bekende formules kom daar ook nog talle ander belangrike merkers in Esegiël 33 voor. Dit sluit ander formules in, asook duidelike verwysings na ander gedeeltes van die boek. Vir die beoordeling van die inhoud en die struktuur van die hoofstuk, is die volgende sake van belang:

- Die datum wat in Esegiël 33:21 aangetref word. Dit is belangrik om daarop te let dat die datum nie aan die begin van hierdie gedeelte van die boek voorkom nie, maar eers by die gedeelte wat die inligting oor die val van Jerusalem bevat.

- Die inleidingsformule 'Die woord van die Here het tot my gekom' in Esegiël 33:1, 23.

- Die aanspreekvorm 'seun van die mens' of 'en jy, seun van die mens' in Esegiël 33:2, 7, 10, 12, 24, 30.

- Die opdrag om met die volk te praat in Esegiël 33:2, 10-12, $25,27$.

- Die boodskapperformule in Esegiël 33:25, 27.

- Aanhaling van die woorde van die volk in Esegiël 33:10, 17, 20, 24, 30.

- Die eedformule 'so waar as Ek leef' in Esegiël 33:11, 27.

- Die bevestigingsformule in Esegiël 33:11.

- Die formule 'die hand van die Here was op my' in Esegiël 33:22.

- Die formule 'dan sal hulle besef dat ek die Here is' in Esegiël 33:29.

- Die formule 'sal hulle besef dat daar 'n profeet tussen hulle was' in Esegiël 33:33.

Al hierdie merkers dra nie dieselfde gewig nie. Die datum in Esegiël 33:21 is baie belangrik in die lig daarvan dat dit die enigste datum in Esegiël 33-39 is. Die volgende twee 
belangrike merkers is die inleidingsformule in Esegiël 33:1 en 23. Wanneer hierdie drie merkers as die uitgangspunt geneem word, word Esegiël 33 in drie dele verdeel, naamlik Esegiël 33:1-20, 21-22 en 22-33.

Die eerste gedeelte, Esegiël 33:1-20, kan weer in 'n aantal onderafdelings verdeel word. In hierdie gedeelte kom twee van die ander merkers ' $n$ hele aantal kere voor. Dit is naamlik die aanspreekvorm 'seun van die mens' of 'en jy, seun van die mens' asook die opdrag aan Esegiël om met die volk te praat. Beide die merkers kom voor in verse 2, 10 en 12 . Die aanspreekvorm kom alleen in vers 7 voor en die opdrag om op sy eie met die volk te praat kom in vers 11 voor. Indien die twee saam as belangrike merkers beskou word, kan die gedeelte van Esegiël 33:1-20 verdeel word in verse 2-9, 10-11 en 12-20. Die twee keer wat hierdie merkers ('seun van die mens' en 'sê vir die volk') op hulle eie voorkom, ondersteun die onderskeiding van verdere onderafdelings in verse $2-6$ en 7-9 en verse 10 en 11 apart. In verse 10 en 11 kom drie van die ander merkers hierbo genoem voor, naamlik die aanhaling van die woorde van die volk in vers 10 en die eedformule en die bevestigingsformule in vers 11 . In die gedeelte van 12-20 kom benewens die twee merkers reeds genoem in vers 12 , die verwysing na die woorde van die volk twee keer voor (in verse 17 en 20) wat dus daarop dui dat verse 12-16 en ook verse $17-20$ as ' $n$ onderafdeling beskou kan word. Die struktuur van die eerste deel van die hoofstuk (Eseg 33:1-20) met ' $n$ aanduiding van die inhoud van die verskillende dele verskyn in Tabel 1.

Wat hier opgemerk kan word, is dat elkeen van die drie afdelings terugverwys na gedeeltes uit die eerste deel van die boek. Die eerste gedeelte het 'n duidelike parallel in Esegiël 3:17-20. Dit geld veral vir 3:17-19 en 33:7-9. In die roepingsvisioen van Esegiël 3 stel God dit duidelik dat hy Esegiël aanstel as wagter vir Israel, en Esegiël 33 herinner Esegiël se gehoor baie direk daaraan. Op hierdie wyse word die profeet se roeping en taak herbeklemtoon (Lapsley 2000:117). Die uiteensetting van Esegiël se taak as wagter word in 33:1-9 breër uitgespel as in hoofstuk 3 (vgl. Lapsley 2000:68-70). Hierdie beeld roep die profeet en sy gehoor op om te luister en daarvolgens op te tree, iets wat vir hulle heeltemal moontlik is (Lapsley 2000:70).

In die tweede gedeelte (Eseg 33:11-12) word daar, in God se antwoord, terugverwys na Esegiël 18:23 en 32. Zimmerli (1983:187) wys dat die woorde dat God wil hê dat die sondaar hom moet bekeer en lewe in Esegiël 18:23 in die vorm van 'n vraag gestel word. Daar vra God of Hy begeer dat die goddelose moet sterf, en antwoord self dat Hy begeer dat die goddelose hom moet bekeer en leef. In hierdie geval word die bevestigingsformule ook aangetref, soos in Esegiël 33:11. In Esegiël 18:32 word dieselfde gedagte in 'n stelling uitgedruk, ook met die bevestigingsformule. In Esegiël 33:11 kom die bevestigingsformule voor en ook 'n stelling, maar die eedformule versterk hierdie stelling verder.

In die eerste onderafdeling van die derde gedeelte (Eseg 33:12-20) word ook terugverwys na Esegiël 18, met die beklemtoning van die mens se persoonlike verantwoordelikheid. Block (1998:247-250) het'n omvattende bespreking van die ooreenkomste en verskille tussen die twee gedeeltes sodat hier nie in besonderhede daarop ingegaan hoef te word nie. In die tweede onderafdeling (Eseg 33:17-20) word ook terugverwys na Esegiël 18, veral verse 25-30, selfs met die herhaling van die aanhaling van die woorde van die volk dat God nie reg optree nie, soos in Esegiël 18.

\section{Inhoud}

Sonder om al die besonderhede te bespreek, is dit baie duidelik dat Esegiël 33:1-20 die lesers van die boek se aandag op baie pertinente sake uit die eerste deel van die boek wil vestig, om so die leser voor te berei vir wat hierop sou volg. Die bedoeling is om oor die uitsprake teen die nasies terug te verwys na die roeping van Esegiël, na die taak wat hy moes uitvoer en na die belangrike uitsprake oor die mens se eie verantwoordelikheid. In hierdie verband speel die aanhaling van die woorde ook 'n belangrike rol, soos aangedui deur Van Rooy en Smit (1991). Deur die volk te wys op die gevolge van sowel verkeerde dade as van bekering wil die profeet dit vir die mense duidelik maak dat daar steeds hoop is (Lemke 1984:168-169). In die boek gebeur dit voor die aankoms van die nuus van die val van Jerusalem, juis om te wys dat die val van Jerusalem nie die einde van God se pad met die volk is nie.

Die tweede gedeelte van die hoofstuk (Eseg 33:21-22) bevat die aankondiging van die val van Jerusalem, asook die gebeure dat die hand van die Here oor Esegiël gekom het die aand voor die aankoms van die boodskapper. Toe het die Here Esegiël in staat gestel om weer te praat. Hierdie gedeelte, wat die enigste datum in Esegiël 33-39 bevat, sluit baie direk aan by die einde van die eerste deel van die boek, Esegiël 24:25-27. Daar vertel die Here vir Esegiël dat daar 'n vlugteling sal kom met die boodskap van die val van Jerusalem en dat die profeet dan weer in staat sal wees om te praat. Dit is egter belangrik om te let op nog 'n frase wat

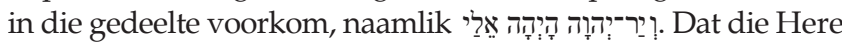
op 'n besondere wyse van Esegiël besit geneem het en hom in sy diens gestel het, kom op verskillende plekke in die boek voor. Dit kom direk aan die begin van die boek voor,

TABEL 1: Die struktuur van Esegiël 33:1-20.

\begin{tabular}{llll}
\hline Merkers uit hoofstuk 33 & & \multicolumn{2}{l}{ Hoofstuk 33 } \\
\cline { 2 - 3 } & Inleiding & Vers & Hoofgedagte \\
\hline Eerste merker & Die beeld van die wagter. & $2-9$ & $\begin{array}{l}\text { Die wagter van 'n stad. } \\
\text { Esegiël as wagter. }\end{array}$ \\
Tweede merker & Die volk se klag en God se antwoord. & $10-12$ & $\begin{array}{l}\text { Ons vergaan. } \\
\text { Bekeer julle! }\end{array}$ \\
Derde merker & $\begin{array}{l}\text { Die gevolge van goeie en slegte dade en } \\
\text { die klagte van die volk daaroor. }\end{array}$ & $12-20$ & $\begin{array}{l}\text { Die gevolge van goeie en slegte dade. } \\
\text { Die volk se klagte en God se antwoord. }\end{array}$ \\
\hline
\end{tabular}


in Esegiël 1:3. Daar word dit wel in die derde persoon gestel, alhoewel op grond van die Septuagint, Peshitta en 'n aantal Masoretiese manuskripte die lesing van die eerste persoon verkieslik is. Later in die roepingsvisioen, in Esegiël 3:15, staan daar dat die hand van die Here sterk was oor Esegiël. Die stelling dat die hand van die Here oor Esegiël was, kom ook voor in Esegiël 3:22, terwyl Esegiël 8:1 sê dat die hand van die Here op die profeet geval het. Die vermelding hiervan in Esegiël 33:22 verwys terug na die eerste deel van die boek. Wat egter belangrik is, is dat hierdie uitdrukking ook twee keer in die boek voorkom na hoofstuk 33, naamlik in Esegiël $37: 1$, ter inleiding van die gesig van die doodsbeendere, en ook in Esegiël 40:1, in die inleiding tot die groot visioen van Esegiël 40-48. In hierdie artikel oor die val van Jerusalem en die nuwe bemagtiging van die profeet, word dus nie net gereflekteer op die eerste deel van die boek nie, maar word belangrike gesigte wat sou kom ook geantisipeer.

Die laaste gedeelte van die hoofstuk, Esegiël 33:23-33, word in twee onderafdelings verdeel deur die aanspreek van die profeet as seun van die mens in verse 24 en 30 . Beide die gedeeltes begin met ' $n$ aanhaling van woorde van die volk. In Esegiël 33:24 word woorde aangehaal van die bewoners van die puinhope van Jerusalem en in Esegiël 33:30 woorde van die ballinge. In beide die gedeeltes kom verskeie van hierdie merkers voor. In die eerste gedeelte word die boodskapperformule na die woorde van die volk aangetref, met 'n boodskap van oordeel oor die bewoners van die puinhope. In die huidige vorm van die boek gaan die uitspraak wel oor die bewoners van die puinhope, maar dit is gerig tot die ballinge. Die herhaling van die boodskapperformule in Esegiël 33:21, asook die eedformule wat direk daarop volg, bevestig die oordeel oor die bewoners van die puinhope. Die resultaat van die oordeel sal wees dat

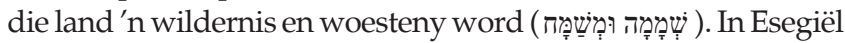
kom die kombinasie van hierdie twee woorde slegs voor in die herhaling van die boodskapperformule in Esegiël 33:21, asook die eedformule wat direk daarop volg in Esegiël 6:14, 33:28 en 29, en 35:3. In Esegiël 6:14 word hulle gebruik in 'n oordeeluitspraak oor Israel, soos ook in Esegiël 33:28 en 29. In Esegiël 35:3 word hulle egter gebruik in 'n oordeeluitspraak oor Edom. Dit dui daarop dat die oordeel oor Israel na Edom, een van die nasies, verplaas word.

Die voltrekking van die oordeel sal daarop uitloop dat die bewoners van die puinhope die mag van die Here sal herken. Hierdie herkenningsformule kom 72 keer in die boek voor, altyd voorafgegaan deur die optrede van die Here, soos ook in hierdie geval (vgl. Lapsley 2000:121-122). Op hierdie wyse antisipeer hierdie boodskap van oordeel die visioen van Esegiël 40-48. Die herstel van die land sal nie gebeur ter wille van diegene wat agtergebly het nie, maar sal tot voordeel wees van diegene wat uit die ballingskap gaan terugkeer.

Die laaste gedeelte van die hoofstuk, Esegiël 33:30-33, begin weer met die aanspreek van die profeet as 'en jy, seun van die mens', gevolg deur 'n verwysing na wat die volk vir mekaar sê. In hierdie geval is die volk die ballinge in Babel. Die gedeelte maak dit duidelik dat die mense die woorde van Esegiël gehoor het. Hulle noem dit selfs die woord van die Here, maar hulle hoor die woord sonder om daarna te luister. Hulle doen nie wat hulle hoor nie. Op die ou einde gaan die woorde egter waar word en dan 'sal hulle besef dat daar 'n profeet in hulle midde was'. Hierdie frase kom net op twee plekke in die boek voor, naamlik in Esegiël 2:5 en hier in Esegiël 33:33. Die aanvanklike boodskap van Esegiël oor die oordeel wat kom, sou in vervulling gaan en dan sou die volk besef dat hy werklik 'n profeet was. Dieselfde geld nou ook vir die nuwe boodskap wat hy gaan aankondig. Wanneer dit in vervulling gaan, sal die volk ook besef dat Esegiël werklik 'n profeet was.

Hierdie twee uitsprake saam skets die omstandighede waarin die volk was, in Jerusalem en in ballingskap, wanneer die nuwe fase van Esegiël se verkondiging begin (Renz 1999:102).

\section{Slot}

\section{Esegiël 33 as wentelpunt in die boek Esegiël}

In die bespreking hierbo word aangedui dat die posisie van Esegiël as wentelpunt in die boek nie beperk moet word tot die verbinding van die hoofstuk met die eerste gedeelte van die boek nie. Daar is inderdaad duidelike verwysings terug, veral in Esegiël 33:1-20, in die besonder na Esegiël 3 en 18. Tog is daar ook sake wat die gedeelte van die boek wat op Esegiël 33 volg, antisipeer. Dit geld in die besonder die twee uitsprake in Esegiël 33:23-33, soos hierbo aangedui, maar ook meer as dit. Die aanduiding van die mens se eie verantwoordelikheid, met die moontlikheid van bekering in Esegiël 33:12-20, vorm hiervan 'n belangrike onderdeel. Esegiël 33 wys dus nie net terug na die eerste gedeelte van die boek nie, maar antisipeer die boodskap van verlossing en herstel in hoofstukke 34 tot 48 .

\section{Erkenning Mededingende belange}

Die outeur verklaar dat hy geen finansiële of persoonlike verbintenis het met enige party wat hom nadelig kon beïnvloed in die skryf van hierdie artikel nie.

\section{Literatuurverwysings}

Allen, L.C., 1990, Ezekiel 20-48, Word Biblical Commentary 28, Dallas, Word. Allen, L.C., 1994, Ezekiel 1-19, Word Biblical Commentary 29, Dallas, Word.

Block, D.I., 1997, The Book of Ezekiel Chapters 1-24, New International Commentary on the Old Testament, Grand Rapids, Eerdmans.

Block, D.I., 1998, The Book of Ezekiel Chapters 25-48, New International Commentary on the Old Testament, Grand Rapids, Eerdmans.

Clements, R.E., 1996, Ezekiel, Westminster Bible Companion, Louisville, Westminster John Knox.

Cooke, G.A., 1970, The Book of Ezekiel, International Critical Commentary, Edinburgh, Clark.

Cooper, L.E., 1994, Ezekiel, New American Commentary 19, Nashville, Broadman \& Holman.

Joyce, P.M., 2009, Ezekiel, A Commentary, Library of Hebrew Bible/Old Testament Studies 482, Clark, New York/London.

Klein, A., 2008, Schriftauslegung im Ezechielbuch, Redaktionsgeschichtliche Untersuchungen zu Ez, 34-39, Beihefte zur Zeitschrift für die alttestamentliche Wissenschaft 391, Berlin/New York, De Gruyter.

Lapsley, J.E., 2000, Can these bones live? The problem of the moral self in the book of Ezekiel, Beihefte zur Zeitschrift für die alttestamentliche Wissenschaft 301, Berlin/ New York, De Gruyter.

Lemke, W.E., 1984, 'Life in the present and hope for the future' [Lewe in die hede en hoop vir die toekoms], Interpretation 38, 165-180.

Renz, T., 1999, 'The rhetorical function of the book of Ezekiel', Vetus Testamentum Supplement 76, Brill, Leiden.

Van Rooy, H.F. \& Smit, E.J., 1990, 'The vox populi and structural aspects of Ezekiel' [Die vox populi en strukturele aspekte van Esegiël], Old Testament Essays 3, 275-285.

Zimmerli, W., 1979, Ezekiel 1, Hermeneia, Fortress, Philadelphia.

Zimmerli, W., 1983, Ezekiel 2, Hermeneia, Fortress, Philadelphia. 